\title{
A Review on Molecular Tools of Microalgal Genetic Transformation and their Application for Overexpression of Different Genes
}

\author{
Jayant Pralhad Rathod ${ }^{1 *}$, Rajendra M. Gade ${ }^{1}$, Darasing R. Rathod ${ }^{2}$ and \\ Mahendra Dudhare ${ }^{1}$ \\ ${ }^{1}$ Vasantrao Naik College of Agricultural Biotechnology, Dr. Panjabrao Deshmukh Krishi \\ Vidyapeeth, Waghapur Road, Yavatmal-445001, Maharashtra, India \\ ${ }^{2}$ Dr. Panjabrao Deshmukh Krishi Vidyapeeth, P.O. Krishi Nagar, Akola-444104, \\ Maharashtra, India \\ *Corresponding author
}

\section{A B S T R A C T}

\section{Keywords \\ Microalgae, Particle \\ bombardment, \\ Agrobacterium \\ mediated \\ transformation, \\ Electroporation, \\ Overexpression, \\ Cloning.}

Article Info

Accepted:

23 October 2017

Available Online:

10 December 2017
Microalgae are in focus because of its tremendous potential to produce different value added compounds such as pigments, polysaccharides, cosmetics, fatty acids, proteins, vitamins and so on. Genetic engineering of microalgae promises broader applications in the field of molecular farming for the production of above mentioned industrially valuable compounds. For transformation of any of these gene widely used molecular tools such as particle bombardment, Agrobacterium mediated transformation, electroporation, and less commonly used Conjugation, Agitation with glass beads, Agitation with silicon carbon whiskers, Protoplast transformation with polyethylene glycol and dimethyl sulfoxide are used. The basic mechanism of these methods is to somehow disturb the cell wall and cell membrane of the algal cell and allow the gene to reach the nucleus via nuclear pore to integrate into the nucleus. Using above mentioned methods genes responsible for lipids, terpenoids, carotenoids and other different therapeutic recombinant proteins have been overexpressed. There are different challenges and existing problems for transformation and integration of genes in microalgae which needs to be overcome to fully utilize the potential of this microbe for molecular cloning and overproduction of different value added compounds.

\section{Introduction}

One of the main challenges for commercial viability of algal technology is low biomass production of microalgae which is utilized for the different value added products. Besides medium engineering and bioreactor designing, genetic engineering is an emerging alternative strategy of combating the problem of low biomass productivity in this field. Genetic engineering of microalgae is a fairly new approach and has been explored in a limited capacity to produce fatty acids enzymes, and vaccines in a limited number of microalgae mainly Chlamydomonas reinhardtii, Dunaliella salina, and Phaeodactylum tricornutum (Rasala et al., 2012; Geng et al., 2003; Hamilton et al., 2014; Vira et al., 2016). The advantages of using these photosynthetic cell factories include biosafety and low cost of substrates in the form of carbon dioxide, light and water 
(Rasala et al., 2014). Different transformation techniques have been developed for the transformation of this very important microorganism which has been mentioned in this review. Besides this, genetic engineering of microalgae has also been employed to modify the metabolism of microalgae, the targets being the genes involved in lipid biosynthetic pathway, photosynthetic activity, carbon assimilation mechanisms, and nutrient metabolism (Gimpel et al., 2015). Overexpression of different genes in microalgae responsible for lipids, terpenoids, carotenoids and other different therapeutic recombinant proteins have been mentioned in this review.

In spite of greater ability and different approaches to produce variety of bioproducts from microalgae, there are technical difficulties and challenges which need to be addressed for commercial exploitation of algal biotechnology.

\section{Molecular tools for algal transformation}

The basis of algal genetic transformation methods is to cause temporal permeabilization of the cell membrane/cell wall enabling DNA molecules to enter the cell, by various physical/ chemical means. Thus, entry of the DNA into the nucleus through nuclear membrane and integration into the genome occurs with or without any external assistance.

The incorporation of DNA into host cell mainly occurs by random recombination, resulting in integration of introduced DNA and, thus culminates in stable/partial genetic transformation (Hallmann, 2007). In reality, permeabilization of a cell membrane in order to introduce the DNA is not difficult; however, the affected algal cell must survive this severe damage i.e. the DNA invasion and recommence cell division at the earliest.

\section{Particle bombardment}

Various transformation methods are available for algal systems that permit the recovery of viable transformants. Amongst these, the most popular method is gene gun transformation also referred to as micro-projectile bombardment, micro-particle bombardment, particle gun transformation, or simply biolistics (Gangl et al., 2015).

In this method, DNA-coated heavy-metal (tungsten/gold) micro-projectiles are used, which allows transformation of nearly any type of cell or cell organelles despite the rigidity or thickness of the cell wall (Fig. 1). This method has been successfully applied in different algal species (Table 1) for basic studies as well for production of different compounds (Gangl et al., 2015). This method is also useful for transformation in chloroplasts (Boynton et al., 1988) and mitochondrial genome of $C$. reinhardtii (Randolph-Anderson et al., 1998).

\section{Electroporation}

Electroporation is yet another method used for genetic transformation in microalgae. Cell-wall reduced mutants, protoplasts, and cells with thin cell walls can be transformed by this method i.e. electroporation.

Electroporation is carried out in specially designed electroporation cuvettes and electroporation chamber where voltage across the plasma membrane exceeds its dielectric strength (Fig. 2). Large electronic pulse allows molecules like DNA to pass the phospholipid bilayer of the cell membrane.

This method was employed in cells of $C$. merolae (Minoda et al., 2004), D. salina (Geng et al., 2003), C. vulgaris (Chow and Tung, 1999) and C. reinhardtii (Brown et al., 1991) successfully (Table 1). 


\section{Agrobacterium-mediated transformation}

Recently, the Agrobacterium-mediated transformation has been demonstrated successfully both in fresh and marine water algal species (Table 1). This gram-negative plant pathogen Agrobacterium tumefaciens has been widely used in genetic engineering of plants (Gangl et al., 2015). The Agrobacterium infection causes tumors mostly in dicots and few monocots, but now demonstrated in certain microalgae are being infected but they do not develop tumors. Thus, Agrobacterium-mediated transformation offers high transformation efficiency with low cost compared to others. The transformation efficiency of Agrobacterium-mediated transformation is reported to enhance in the presence of acetosyringone by activating the vir genes of Agrobacterium (Stachel et al., 1985; Men et al., 2003; Kumar et al., 2004). The gene of interest gets transferred to the algal nucleolus with the help of vir gene and randomly integrates into the nuclear DNA (Fig. 3). However, there is a report of Agrobacteriummediated transformation of $H$. pluvialis cells without the use of acetosyringone (Kathiresan et al., 2009). This method is preferred over other methods mostly because of high chances of integration of gene into the algal genome at a specific site.

\section{Glass bead/inert particle mediated transformation}

Alternatively, another less complex and less expensive transformation method involves agitation of microalgae with small inert particles and DNA. It involves preparation of homogenous suspension of microalgae that is agitated with DNA in the presence of macroor micro-particles, and polyethylene glycol. A number of investigators have also used silicon carbide whiskers $(\sim 0.3-0.6 \mu \mathrm{m}$ thick and $\sim 5$ $15 \mu \mathrm{m}$ long) as micro-particles which is a ceramic compound composed of silicon and carbon. These hard and rigid micro-particles are efficient in genetically transforming cells with intact cell walls. The examples include Amphidinium sp. (Te Lohuis and Miller, 1998) Symbiodinium microadriaticum (Te Lohuis and Miller, 1998), and $C$. reinhardtii (Dunahay, 1993). Although microalgae with cell wall get transformed by this method, but cell wall reduced microalgae provide more advantage in terms of higher transformation efficiency. The cell wall reduced mutants of $C$. reinhardtii have been transformed through agitation in the presence of glass beads (0.4-0.5 mm in diameter) along with DNA and polyethylene glycol (Kindle, 1990). Most investigators prefer to work with cell wall less strains, thus this easy and cheap method is routinely used for transforming $C$. reinhardtii. In case of $C$. ellipsoidea, cell-wall free protoplasts were transformed without any micro- or macro-particles by only agitation of the protoplast in the presence of DNA and polyethylene glycol (Jarvis and Brown, 1991).

Thus, there are considerable ways of introducing DNA into algal cells. The most widely used method for genetic transformation is particle bombardment as depicted in Table 1 because of its ability to transform all kinds of cells irrespective of the cell wall composition. The only hurdle in this method is the cost of the instrument and remarkable running expenses. The second preferred method is electroporation which has same advantages as particle bombardment of being simple and quick method for transformation. Agrobacterium-mediated transformation has been used for a couple of algal species and is gaining momentum because of less cost requirement during cell transformation. Other methods such as conjugation, agitation and protoplast transformation methods have also been applied for different algal species though they are not routine methods. The glass bead 
method is classified as frequently used method for model organism C. reinhardtii which is quick and easy method of transformation. In conclusion, the method of transformation can be defined based on species and cell wall physiology of the microalgae.

\section{Potential applications of genetic transformation in microalgae}

The potential of microalgae have been demonstrated by their ability to produce lipids, antioxidants, high-value bioactive compounds, and proteins such as vaccines, antibodies, and hormones by using genetic engineering.

Microalgae have been targeted for biofuel production owing to its suitable features as mentioned earlier. Genetic manipulation is a promising strategy for the over-production of lipids among algal species and different metabolic engineering strategies were employed for increasing lipid production as listed in Table 2.

Studies have also been carried out to reveal the role of genes in the regulation of algal lipid accumulation (Guckert and Cooksey, 1990). The algal cells accumulate lipid under different stress conditions which inhibits cell cycle progression (Guckert and Cooksey, 1990).

Under nitrogen stress, transcriptomic and proteomic analysis showed up-regulation of mRNAs and proteins associated with fatty acid and lipid biosynthesis (Miller et al., 2010; Guarnieri et al., 2011). A number of potential gene targets which are involved in lipid biosynthesis and regulation were targeted and higher lipid productivity was achieved in different microalgal species (Li et al., 2010). Reports suggest that elimination of starch synthesis pathway would switch photosynthetic carbon flux toward triacylglyceride (TAG) synthesis (Li et al., 2010).

Along with lipids, other high-value added compounds will be produced from the microalgae using algal transgenics such as terpenoids and carotenoids. The examples for different terpenoids and carotenoids production in microalgae are listed in Table 3.

Microalgae have also been established as useful bioreactors for the expression of valuable proteins such as vaccines, antibodies, enzymes and hormones (Gan et al., 2016).

Specifically $C$. reinhardtii has been targeted for the production of recombinant protein production owing to its well characterized genome, functional mutants and genetic transformation tools available for transformation (Lauersen et al., 2012).

The examples of different recombinant proteins produced in microalgae are mentioned in Table 4.

In addition to the above products, genetic engineering of microalgae has also been used in carbon capturing mechanism, aquaculture and in production of essential oils (Gangl et al., 2015).

Several attempts have been made to improve the photosynthetic efficiency of microalgae; most of these are focused on reducing the size of the chlorophyll antenna by using different techniques including the most efficient RNAibased strategy to knock down both LHCI and LHCII in C. reinhardtii (Zeng et al., 2011).

In $P$. tricornutum, overexpression of $\Delta 5$ elongase gene from $O$. tauri helped in accumulation of high value omega-3 polyunsaturated fatty acid docosahexaenoic acid (DHA) (Hamilton et al., 2014). 
Fig.1 Particle bombardment system and mechanism

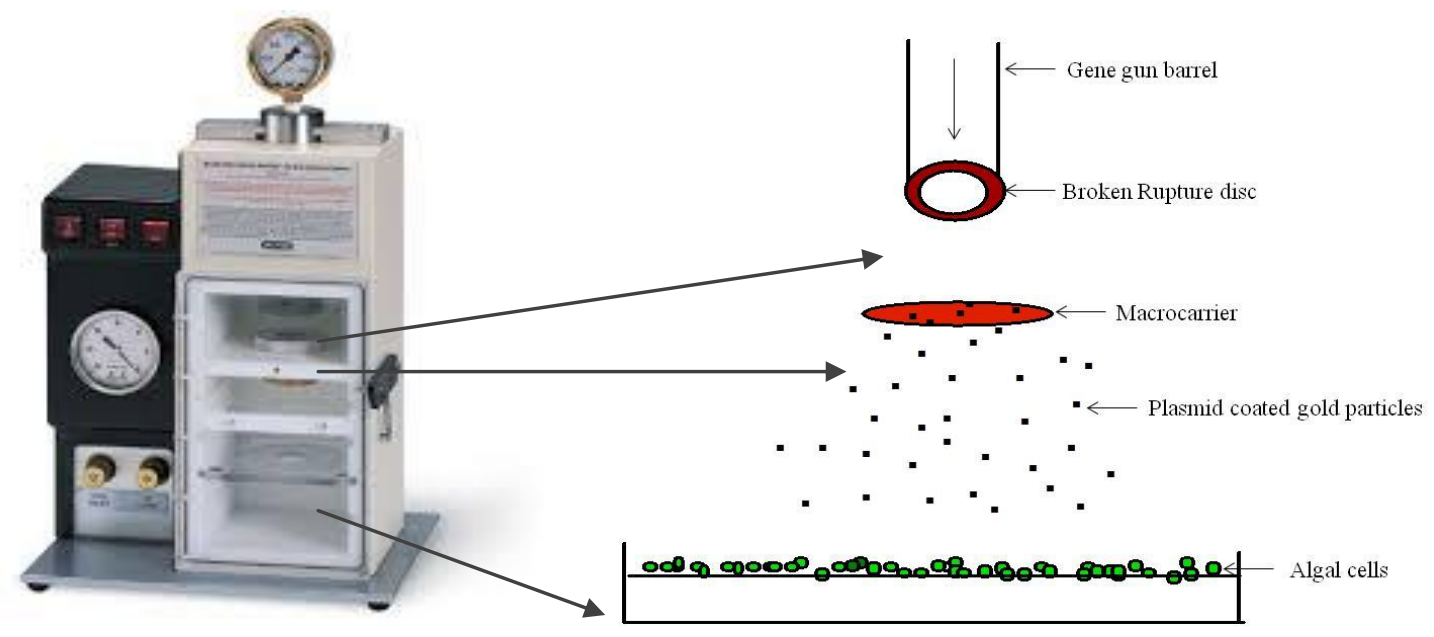

Fig.2 Electroporation apparatus and mechanism
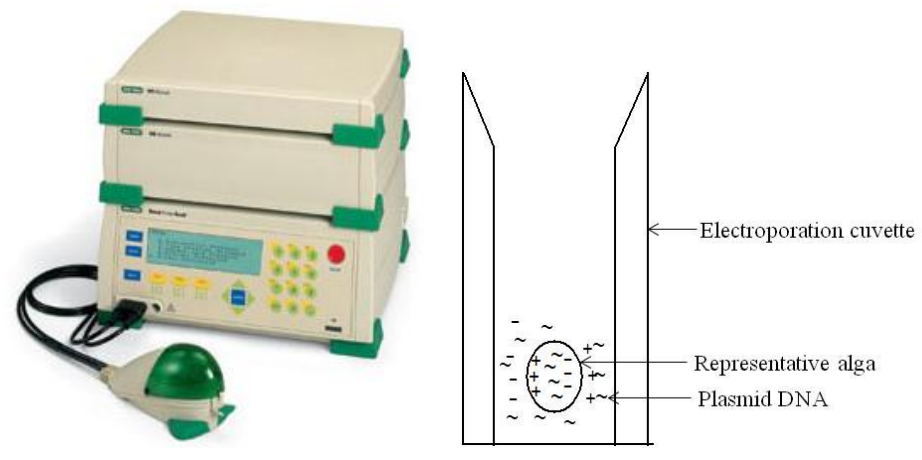

Fig.3 Mechanism of Agrobacterium-mediated transformation

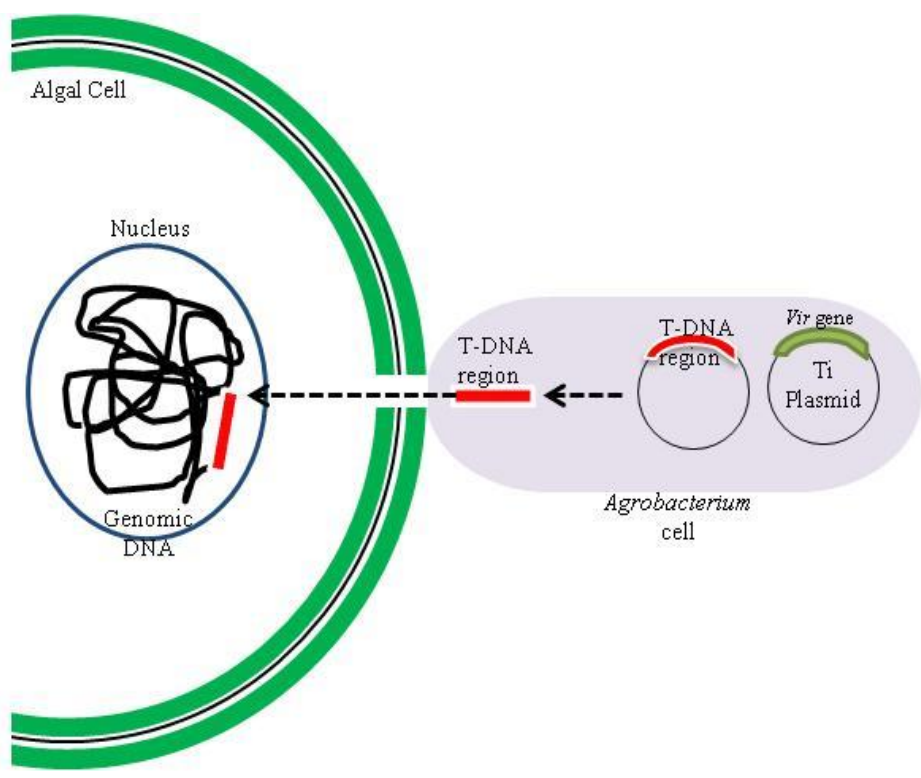


Table.1 Methods of algal transformation

\begin{tabular}{|c|c|c|}
\hline Transformation method & Transformed algal species & Reference \\
\hline \multirow[t]{21}{*}{ Particle bombardment } & C. reinhardtii & Mayfield et al., 2004 \\
\hline & & Sun et al., 2003 \\
\hline & & Bateman and Purton, 2000 \\
\hline & & Debuchy et al., 1989 \\
\hline & & Kindle et al., 1989 \\
\hline & P. tricornutum & Miyagawa et al., 2009 \\
\hline & & Zaslavskaia et al., 2001 \\
\hline & & Falciatore et al., 1999 \\
\hline & & Apt et al., 1996 \\
\hline & Chlorella zofingiensis & Liu et al., 2014 \\
\hline & Parachlorella kessleri & Rathod et al., 2016 \\
\hline & H. pluvialis & Steinbrenner and Sandmann, 2006 \\
\hline & D. salina & Tan et al., 2005 \\
\hline & Gracilaria changii & Gan et al., 2003 \\
\hline & Porphyridium sp. & Lapidot et al., 2002 \\
\hline & Euglena gracilis & Doetsch et al., 2001 \\
\hline & L. japonica & Qin et al., 1999 \\
\hline & C. kessleri & El-Sheekh, 1999 \\
\hline & Chlorella sorokiniana & Dawson et al., 1997 \\
\hline & Navicula saprophila & Dunahay et al., 1995 \\
\hline & Cyclotella cryptica & Dunahay et al., 1995 \\
\hline \multirow{8}{*}{ Electroporation } & C. zofingiensis & Liu et al., 2014 \\
\hline & Scenedesmus obliquus & Guo et al., 2013 \\
\hline & C. vulgaris & Niu et al., 2011 \\
\hline & C. vulgaris & Chow and Tung, 1999 \\
\hline & C. merolae & Minoda et al., 2004 \\
\hline & D. salina & Geng et al., 2003 \\
\hline & U. lactuca & Huang et al., 1996 \\
\hline & C. reinhardtii & Brown et al., 1991 \\
\hline \multirow{9}{*}{$\begin{array}{c}\text { Agrobacterium-mediated } \\
\text { transformation }\end{array}$} & C. vulgaris & Sharif et al., 2015 \\
\hline & Scenedesmus almeriensis & Dautor et al., 2014 \\
\hline & Parachlorella kessleri & Rathod et al., 2013 \\
\hline & Schizochytrium sp. & Cheng et al., 2012 \\
\hline & C. vulgaris & Cha et al., 2012 \\
\hline & D. bardawil & Anila et al., 2011 \\
\hline & Nannochloropsis sp. & Cha et al., 2011 \\
\hline & Chaetoceros sp. & Miyagawa et al., 2011 \\
\hline & H. pluvialis & Kathiresan et al., 2009 \\
\hline \multirow[t]{4}{*}{ Conjugation } & Prochlorococcus & (Tolonen et al., 2006) \\
\hline & Pseudanabaena & (Sode et al., 1992) \\
\hline & Synechococcus & (Sode et al., 1992; Brahamsha, 1996) \\
\hline & Synechocystis & (Sode et al., 1992) \\
\hline \multirow[t]{3}{*}{ Agitation with glass beads } & C. reinhardtii & León et al., \\
\hline & & $\begin{array}{l}\text { 2007; Ohresser } \text { et al., 1997; Purton } \\
\text { and Rochaix, 1995; } \\
\text { Kindle, 1990; }\end{array}$ \\
\hline & D. salina & Feng et al., 2009 \\
\hline Agitation with silicon carbon whiskers & Amphidinium sp. & Te Lohuis and Miller, 1998 \\
\hline \multirow{4}{*}{$\begin{array}{l}\text { Protoplast transformation with } \\
\text { polyethylene glycol and dimethyl } \\
\text { sulfoxide }\end{array}$} & Symbiodinium microadriaticum & $\begin{array}{l}\text { Te Lohuis and Miller, } \\
1998\end{array}$ \\
\hline & C. reinhardtii & Dunahay, 1993 \\
\hline & Pleurochrysis carterae & Endo et al., 2016 \\
\hline & $\begin{array}{l}\text { C. ellipsoidea } \\
\text { Chlorella }\end{array}$ & $\begin{array}{l}\text { Kim et al., } 2002 \\
\text { Hawkins and Nakamura, } 1999\end{array}$ \\
\hline
\end{tabular}


Table.2 Metabolic engineering of microalgae for lipid production

\begin{tabular}{|c|c|c|c|}
\hline Algal strain & Target protein & Outcome of transformation & Reference \\
\hline \multirow[t]{6}{*}{ C. reinhardtii } & $\begin{array}{l}\text { Diacylglycerol } \\
\text { acyltransferase }\end{array}$ & $\begin{array}{l}\text { Polyunsaturated fatty acids, } \\
\text { especially } \alpha \text {-linolenic acid, an } \\
\text { essential omega- } 3 \text { fatty acid, were } \\
\text { enhanced up to } 12 \%\end{array}$ & $\begin{array}{l}\text { Ahmad et } \\
\text { al., } 2015\end{array}$ \\
\hline & $\begin{array}{l}\text { Fatty acid-ACP } \\
\text { thioesterase }\end{array}$ & $\begin{array}{l}\text { Shorter chain FA with the } \\
\text { endogenous gene and no increase } \\
\text { in lipids for all genes }\end{array}$ & $\begin{array}{l}\text { Blatti et al., } \\
2012\end{array}$ \\
\hline & $\begin{array}{l}\text { Acyl-Coa: } \\
\text { diacylglycerol } \\
\text { acyltransferase }\end{array}$ & $\begin{array}{l}\text { No increase in TAG } \\
\text { accumulation and TAG profiles }\end{array}$ & $\begin{array}{l}\text { La Russa et } \\
\text { al., } 2012\end{array}$ \\
\hline & $\begin{array}{l}\text { Acyl-CoA: } \\
\text { diacylglycerol } \\
\text { acyltransferase }\end{array}$ & $\begin{array}{l}34 \% \text { increase in TAGs with one } \\
\text { gene; } 24 \% \text { and } 37 \% \text { decrease in } \\
\text { TAGs with two genes }\end{array}$ & $\begin{array}{l}\text { Deng et al., } \\
2012\end{array}$ \\
\hline & $\begin{array}{l}\text { Lipid trigger } \\
\text { transcription factor }\end{array}$ & $\begin{array}{l}\text { Total extractable lipids increased } \\
\text { by } 11 \%\end{array}$ & $\begin{array}{l}\text { Yohn et al., } \\
2012\end{array}$ \\
\hline & $\Delta 4$ desaturase & $\begin{array}{l}\text { Increased accumulation of FA } \\
16: 4\end{array}$ & $\begin{array}{l}\text { Zäuner et al., } \\
2012\end{array}$ \\
\hline \multirow[t]{5}{*}{ P. tricornutum } & $\begin{array}{l}\text { Pyruvate } \\
\text { dehydroganase } \\
\text { kinase }\end{array}$ & Neutral lipids increase by $82 \%$ & $\begin{array}{l}\text { Ma et al., } \\
2014\end{array}$ \\
\hline & Malic enzyme & $\begin{array}{l}\text { Total lipids increased by } 2.5 \\
\text { times }\end{array}$ & $\begin{array}{l}\text { Xue et al., } \\
2014\end{array}$ \\
\hline & $\triangle 5$ desaturase & $\begin{array}{l}65 \% \text { more neutral FA with } 58 \% \\
\text { increased accumulation of EPA }\end{array}$ & $\begin{array}{l}\text { Peng et al., } \\
2014\end{array}$ \\
\hline & $\begin{array}{l}\text { Fatty acid }(F A)- \\
\text { ACP thioesterase }\end{array}$ & $\begin{array}{l}\text { Increased production of } \mathrm{C} 12 \text { and } \\
\mathrm{C} 14 \mathrm{FA}\end{array}$ & $\begin{array}{l}\text { Radakovits } \\
\text { et al., } 2011\end{array}$ \\
\hline & $\begin{array}{l}\text { Fatty acid-ACP } \\
\text { thioesterase } \\
\text { (Endogenous) }\end{array}$ & $82 \%$ increase in total FAs & $\begin{array}{l}\text { Gong et al., } \\
2011 \mathrm{a}\end{array}$ \\
\hline $\begin{array}{l}\text { Thalassiosira } \\
\text { pseudonana }\end{array}$ & $\begin{array}{l}\text { Multifunctional } \\
\text { lipase }\end{array}$ & Total lipids increased by 3.3 fold. & $\begin{array}{l}\text { Trentacoste } \\
\text { et al., } 2013\end{array}$ \\
\hline $\begin{array}{c}\text { Chlorella } \\
\text { minutissima }\end{array}$ & $\begin{array}{l}\text { Five TAG } \\
\text { biosynthetic } \\
\text { enzymes }\end{array}$ & $\begin{array}{l}\text { No change with individual genes } \\
\text { but increase in TAGS with five } \\
\text { genes }\end{array}$ & $\begin{array}{l}\text { Hsieh et al., } \\
2012\end{array}$ \\
\hline C. cryptic & $\begin{array}{l}\text { Acetyl-CoA } \\
\text { carboxylase }\end{array}$ & $\begin{array}{l}\text { No increase in total lipid } \\
\text { accumulation }\end{array}$ & $\begin{array}{l}\text { Dunahay et } \\
\text { al., } 1996\end{array}$ \\
\hline
\end{tabular}


Table.3 Production of terpenoids and carotenoids in microalgae through genetic engineering

\begin{tabular}{|c|c|c|c|}
\hline Algal strain & Target protein/enzyme & Outcome of transformation & Reference \\
\hline \multirow[t]{9}{*}{ C. reinhardtii } & Squalene synthase & Squalene was not detected & Kajikawa et al., 2015 \\
\hline & Squalene epoxidase & $\begin{array}{l}\text { Detection upto } 1.1\left(\mu \mathrm{g} \mathrm{mg}^{-1}\right) \text { dry weight of } \\
\text { squalene }\end{array}$ & Kajikawa et al., 2015 \\
\hline & Phytoene desaturase & $\begin{array}{l}\text { Norflurazon resistance and Increase of } \\
\text { different carotenoids }\end{array}$ & Liu et al., 2013 \\
\hline & Phytoene synthase & Increase in lutein content by 2.6 times & Couso et al., 2011 \\
\hline & Phytoene synthase & Increase in lutein content by 2.2 times & Cordero et al., 2011 \\
\hline & Phytoene desaturase & No significant changes in carotenoid profile & Vila et al., 2008 \\
\hline & $\beta$-caroteneketolase & $\begin{array}{l}\text { Detection of 4-keto-lutein but no astaxanthin } \\
\text { detected }\end{array}$ & Leon et al., 2007 \\
\hline & $\beta$-caroteneketolase & keto-carotenoids not detected & Wong, 2006 \\
\hline & $\begin{array}{l}\text { Geranylgeranyl- } \\
\text { pyrophosphate synthase }\end{array}$ & No changes in carotenoids/isoprenoid profile & Fukusaki et al., 2003 \\
\hline C. zofingiensis & Phytoene desaturase & $\begin{array}{l}54.1 \% \text { increase in astaxanthin and } 32.1 \% \\
\text { increase in total carotenoids }\end{array}$ & Liu et al., 2014 \\
\hline D. salina & Phytoene desaturase & Carotenoid profiles not reported & Sun et al., 2008 \\
\hline H. pluvialis & Phytoene desaturase & $\begin{array}{l}\text { Norflurazon resistance and } 26 \% \text { increase in } \\
\text { astaxanthin }\end{array}$ & $\begin{array}{l}\text { Steinbrenner and } \\
\text { Sandmann, } 2006\end{array}$ \\
\hline
\end{tabular}

Table.4 Production of recombinant proteins in microalgae by using genetic engineering approach

\begin{tabular}{|c|c|c|}
\hline Gene overexpressed & Function & Reference \\
\hline $10 \mathrm{NF} 3,14 \mathrm{FN3}$ & $\begin{array}{l}\text { Domains } 10 \text { and } 14 \text { of human fibronectin, potential } \\
\text { antibody mimics14FN3 }\end{array}$ & Rasala et al., 2010 \\
\hline $83 K 7 C$ & $\begin{array}{l}\text { Full-length } \operatorname{IgG} 1 \text { human monoclonal antibody against } \\
\text { anthrax protective antigen } 83\end{array}$ & Tran et al., 2009 \\
\hline ARS2-crEpo-his6 & $\begin{array}{l}\text { Human erythropoietin fused to ARS } 2 \text { export sequence } \\
\text { w/6xhis tag }\end{array}$ & Eichler-Stahlberg et al., 2009 \\
\hline CSFV-E2 & Swine fever virus E2 viral protein & He et al., 2007 \\
\hline CTB-D2 & $\begin{array}{l}\text { D2 fibronectin-binding domain of Staphylococcus aureus } \\
\text { fused with the cholera toxin B subunit }\end{array}$ & Dreesen et al., 2010 \\
\hline CTB-VP1 & $\begin{array}{l}\text { Cholera toxin B subunit fused to foot and mouth disease } \\
\text { VP1 }\end{array}$ & Sun et al., 2003 \\
\hline hGAD65 & $\begin{array}{l}\text { Diabetes-associated anutoantigen human glutamic acid } \\
\text { decarboxylase } 65\end{array}$ & Wang et al., 2008 \\
\hline hGH & Human growth hormone & Geng et al., 2013 \\
\hline HMGB1 & High mobility group protein $\mathrm{B} 1$ & Rasala et al., 2010 \\
\hline hMT-2 & Human metallothionine-2 & Zhang et al., 2006 \\
\hline HSV8-Isc & First mammalian protein expressed & Mayfield et al., 2003 \\
\hline HSV8-scFv & Classic single-chain antibody & Mayfield et al., 2005 \\
\hline hTRAIL & $\begin{array}{l}\text { Human tumor necrosis factor-related apoptosis-inducing } \\
\text { ligan d (TRAIL) }\end{array}$ & Yang et al., 2006 \\
\hline IgG1 & Murine and human antibodies & Tran et al., 2009 \\
\hline M-SAA & Bovine mammary-associated serum amyloid & Manuell et al., 2007 \\
\hline M-SAA- Interferon $\beta 1$ & Multiple sclerosis treatment fused to M-SAA & Rasala et al., 2010 \\
\hline Proinsulin & $\begin{array}{l}\text { Blood sugar level-regulating hormone, type I diabetes } \\
\text { treatment }\end{array}$ & Rasala et al., 2010 \\
\hline VEGF & Human vascular endothelial growth factor isoform 121 & Rasala et al., 2010 \\
\hline VP28 & White spot syndrome virus protein 28 & Surzycki et al., 2009 \\
\hline Xylanase1 & Commercial enzyme & Rasala et al., 2012 \\
\hline
\end{tabular}




\section{Existing problems}

Genetic engineering in microalgae is a challenging science to understand and cater the needs of eukaryotic system due to its complexity of nuclear genome and tougher cell wall, which pose hints for establishing the transformation protocols in species of interest. Even after establishment of transformation methodologies, selection of positive transformants among false positives will be a rate limiting challenge. The frequency of transgene expression in nuclear genome of microalgae is extremely low due to presence of gene silencing. Few of the indicated reasons for gene silencing are DNA methylation, positional effects and epigenetic mechanisms (Hallman, 2007). It is often related to several factors such as the control of developmental stages and the response of a cell to transposable elements, or other foreign DNA or unnaturally placed DNA (Wu-Scharf et al., 2000; Cerutti et al., 1997). The possible solution to this problem is screening of a larger number of transformants which are expressing higher amounts of protein.

The transgene expression of heterologous origin in microalgae is further hampered on account of codon bias, which is typical for almost all the species. When commonly used codons of the DNA donor species are infrequently found in the genes of the target organism, the corresponding tRNA abundance becomes very low and this led to less or no translation and expression of the desired protein. The situation can be worst when the codon is not present at all in the target species. One strategy to circumvent this problem is to look for heterologous gene source from different organisms that have codon usage similar to genes of the target organism. Thus, the Streptoalloteichus hindustanus (ble) gene was recognized as efficient selectable marker for transformation of both V. carteri (Hallmann and Rappel,
1999) and C. reinhardtii (Stevens et al., 1996). Another approach is to completely resynthesize the heterologous gene by using codon optimization for the target species.

Another difficulty in transgenesis of microalgae is the presence of introns in heterologous gene. Heterologous genes with introns will likely not be spliced correctly, thus cDNAs should be used. However, the problem in this case is poor expression of transgene. This problem can be solved by inserting homologous introns into the heterologous coding region. The usefulness of such chimeric genes has been already demonstrated in $V$. carteri (Hallmann and Rappel, 1999) and C. reinhardtii species (Lumbreras et al., 1998).

Another reason for lower expression is due to choice of promoter component. The heterologous promoters, like CaMV35S and SV40 promoters have been demonstrated to work in some species, but not in all algal species (Hallmann, 2007). One of the possible reason behind this maybe inadequate recognition of the heterologous promoter region and lack of adequate regulation; thus heterologous $3^{\prime}$ untranslated regions may cause incorrect polyadenylation and can also inauspiciously influence regulation (Hallman, 2007). Therefore, use of endogenous promoter for specific species of interest is highly recommended. Major troubleshooting maybe due to insufficient DNA delivery, failure to integrate into the host organism's genome, and false positive results can be because of adaptability of microalgae to the antibiotics, or improper transport through the plasma membrane into the extracellular compartment or into the chloroplast. Till date, studies on genetic engineering have been demonstrated in model microalga such as $C$. reinhardtii and $P$. tricornutum due to the availability of molecular tools. Profound optimized protocols are required to develop 
and understand algal transgenics, which will aim to provide molecular tools that are compatible and promising future for genetic engineering in microalgae.

\section{References}

Ahmad, I., Sharma, A. K., Daniell, H., and Kumar, S. (2015). Altered lipid composition and enhanced lipid production in green microalga by introduction of brassica diacylglycerol acyltransferase 2. Plant biotechnology journal, 13(4), 540-550.

Anbuchezhian, R., Karuppiah, V., and Li, Z. (2015). Prospect of marine algae for production of industrially important chemicals. In Algal Biorefinery: An Integrated Approach Springer International Publishing, (pp. 195-217).

Anila, N., Chandrashekar, A., Ravishankar, G. A., and Sarada, R. (2011). Establishment of Agrobacterium tumefaciens-mediated genetic transformation in Dunaliella bardawil. European Journal of phycology, 46(1), 36-44.

Apt, K. E., Grossman, A. R., and KrothPancic, P. G. (1996). Stable nuclear transformation of the diatom Phaeodactylum tricornutum. Molecular and General Genetics MGG, 252(5), 572-579.

Bateman, J. M., and Purton, S. (2000). Tools for chloroplast transformation in Chlamydomonas: expression vectors and a new dominant selectable marker.Molecular and General Genetics MGG, 263(3), 404-410.

Blatti, J. L., Beld, J., Behnke, C. A., Mendez, M., Mayfield, S. P., and Burkart, M. D. (2012). Manipulating fatty acid biosynthesis in microalgae for biofuel through protein-protein interactions. PLoS One, 7(9), e42949.

Boynton, J. E., Gillham, N. W., Harris, E. H.,
Hosler, J. P., Johnson, A. M., Jones, A. R., and Shark, K. B. (1988). Chloroplast transformation in Chlamydomonas with high velocity microprojectiles. Science, 240(4858), 1534-1538.

Brahamsha, B. (1996). An abundant cellsurface polypeptide is required for swimming by the nonflagellated marine cyanobacterium Synechococcus. Proceedings of the National Academy of Sciences, 93(13), 6504-6509.

Brown, L. E., Sprecher, S. L., and Keller, L. R. (1991). Introduction of exogenous DNA into Chlamydomonas reinhardtii by electroporation. Molecular and cellular biology, 11(4), 2328-2332.

Cerutti, H., Johnson, A. M., Gillham, N. W., and Boynton, J. E. (1997). A eubacterial gene conferring spectinomycin resistance on Chlamydomonas reinhardtii: integration into the nuclear genome and gene expression. Genetics, 145(1), 97-110.

Cha, Thye-San, et al., Cinnamic acid, coumarin and vanillin: Alternative phenolic compounds for efficient Agrobacterium-mediated transformation of the unicellular green alga, Nannochloropsis sp. Journal of microbiological methods, 84.3 (2011): 430-434.

Cheng, R., Ma, R., Li, K., Rong, H., Lin, X., Wang, Z., and Ma, Y. (2012). Agrobacterium tumefaciens mediated transformation of marine microalgae Schizochytrium. Microbiological research, 167(3), 179-186.

Chow, K. C., and Tung, W. L. (1999). Electrotransformation of Chlorella vulgaris. Plant Cell Reports, 18(9), 778780.

Cordero, B. F., Couso, I., León, R., Rodríguez, H., and Vargas, M. Á. (2011). Enhancement of carotenoids biosynthesis in Chlamydomonas reinhardtii by nuclear transformation 
using a phytoene synthase gene isolated from Chlorella zofingiensis. Applied microbiology and biotechnology, 91(2), 341-351.

Couso, I., Vila, M., Rodriguez, H., Vargas, M. A., and Leon, R. (2011). Overexpression of an exogenous phytoene synthase gene in the unicellular alga Chlamydomonas reinhardtii leads to an increase in the content of carotenoids. Biotechnology progress, 27(1), 54-60.

Dautor, Y., Úbeda-Mínguez, P., Chileh, T., García-Maroto, F., and Alonso, D. L. (2014). Development of genetic transformation methodologies for an industrially-promising microalga: Scenedesmus almeriensis. Biotechnology letters, 36(12), 25512558.

Dawson, H. N., Burlingame, R., and Cannons, A. C. (1997). Stable transformation of Chlorella: rescue of nitrate reductasedeficient mutants with the nitrate reductase gene. Current microbiology, 35(6), 356-362.

Debuchy, R., Purton, S., and Rochaix, J. D. (1989). The argininosuccinate lyase gene of Chlamydomonas reinhardtii: an important tool for nuclear transformation and for correlating the genetic and molecular maps of the ARG7 locus. The EMBO journal, 8(10), 2803.

Deng, X. D., Gu, B., Li, Y. J., Hu, X. W., Guo, J. C., and Fei, X. W. (2012). The roles of acyl-CoA: diacylglycerol acyltransferase 2 genes in the biosynthesis of triacylglycerols by the green algae Chlamydomonas reinhardtii. Molecular plant, 5(4), 945947.

Doetsch, N. A., Favreau, M. R., Kuscuoglu, N., Thompson, M. D., and Hallick, R. B. (2001). Chloroplast transformation in Euglena gracilis: splicing of a group III twintron transcribed from a transgenic psbK operon. Current genetics, 39(1), 49-60.

Dreesen, I. A., Charpin-El Hamri, G., and Fussenegger, M. (2010). Heat-stable oral alga-based vaccine protects mice from Staphylococcus aureus infection. Journal of biotechnology, 145(3), 273280.

Dunahay, T. G. (1993). Transformation of Chlamydomonas reinhardtii with silicon carbide whiskers. Biotechniques, 15(3), 452-5.

Dunahay, T. G., Jarvis, E. E., and Roessler, P. G. (1995). Genetic transformation of the diatoms Cyclotella cryptica and Navicula saprophila. Journal of Phycology, 31(6), 1004-1012.

Dunahay, T. G., Jarvis, E. E., Dais, S. S., and Roessler, P. G. (1996). Manipulation of microalgal lipid production using genetic engineering. In Seventeenth Symposium on Biotechnology for Fuels and Chemicals (pp. 223-231). Humana Press.

Eichler-Stahlberg, A., Weisheit, W., Ruecker, O., and Heitzer, M. (2009). Strategies to facilitate transgene expression in Chlamydomonas reinhardtii. Planta, 229(4), 873-883.

El-Sheekh, M. M. (1999). Stable transformation of the intact cells of Chlorella kessleri with high velocity microprojectiles. Biologia Plantarum, 42(2), 209-216.

Endo, H., Yoshida, M., Uji, T., Saga, N., Inoue, K., and Nagasawa, H. (2016). Stable nuclear transformation system for the coccolithophorid alga Pleurochrysis carterae. Scientific reports, 6.

Falciatore, A., Casotti, R., Leblanc, C., Abrescia, C., and Bowler, C. (1999). Transformation of nonselectable reporter genes in marine diatoms. Marine Biotechnology, 1(3), 239-251. 
Feng, S., Xue, L., Liu, H., and Lu, P. (2009). Improvement of efficiency of genetic transformation for Dunaliella salina by glass beads method. Molecular biology reports, 36(6), 1433-1439.

Fukusaki, E. I., Nishikawa, T., Kato, K., Shinmyo, A., Hemmi, H., Nishino, T., and Kobayashi, A. (2003). Introduction of the archaebacterial geranylgeranyl pyrophosphate synthase gene into Chlamydomonas reinhardtii chloroplast. Journal of bioscience and bioengineering, 95(3), 283-287.

Gan, S. Y., Lim, P. E., and Phang, S. M. (2016). Genetic and Metabolic Engineering of Microalgae. In Algae Biotechnology (pp. 317-344). Springer International Publishing.

Gan, S. Y., Qin, S., Othman, R. Y., Yu, D., and Phang, S. M. (2003). Transient expression of lac $Z$ in particle bombarded Gracilaria changii (Gracilariales, Rhodophyta). Journal of Applied Phycology, 15(4), 345-349.

Gangl, D., Zedler, J. A., Rajakumar, P. D., Martinez, E. M. R., Riseley, A., Włodarczyk, A., and Robinson, C. (2015). Biotechnological exploitation of microalgae. Journal of Experimental Botany, 66(22), 6975-6990.

Geng, D., Wang, Y., Wang, P., Li, W., and Sun, Y. (2003). Stable expression of hepatitis B surface antigen gene in Dunaliella salina (Chlorophyta). Journal of applied phycology, 15(6), 451-456.

Gimpel, J. A., Hyun, J. S., Schoepp, N. G., and Mayfield, S. P. (2015). Production of recombinant proteins in microalgae at pilot greenhouse scale. Biotechnology and bioengineering, 112(2), 339-345.

Gong, Y., Guo, X., Wan, X., Liang, Z., and Jiang, M. (2011). Characterization of a novel thioesterase (PtTE) from Phaeodactylum tricornutum. Journal of basic microbiology, 51(6), 666-672.
Guarnieri, M. T., Nag, A., Smolinski, S. L., Darzins, A., Seibert, M., and Pienkos, P. T. (2011). Examination of triacylglycerol biosynthetic pathways via de novo transcriptomic and proteomic analyses in an unsequenced microalga. PLoS One, 6(10), e25851.

Guckert, J. B., and Cooksey, K. E. (1990). Triglyceride accumulation and fatty acid profile changes in Chlorella (Chlorophyta) during high $\mathrm{pH}$ - induced cell cycle inhibition. Journal of Phycology, 26(1), 72-79.

Guo, S. L., Zhao, X. Q., Wan, C., Huang, Z. Y., Yang, Y. L., Alam, M. A., and Chang, J. S. (2013). Characterization of flocculating agent from the selfflocculating microalga Scenedesmus obliquus AS-6-1 for efficient biomass harvest. Bioresource technology, 145, 285-289.

Hallmann, A. (2007). Algal transgenics and biotechnology. Transgenic Plant $J$, 1(1), 81-98.

Hallmann, A., and Rappel, A. (1999). Genetic engineering of the multicellular green alga Volvox: a modified and multiplied bacterial antibiotic resistance gene as a dominant selectable marker. The Plant Journal, 17(1), 99-109.

Hamilton, M. L., Haslam, R. P., Napier, J. A., and Sayanova, O. (2014). Metabolic engineering of Phaeodactylum tricornutum for the enhanced accumulation of omega-3 long chain polyunsaturated fatty acids. Metabolic engineering, 22, 3-9.

Hawkins, R. L., and Nakamura, M. (1999). Expression of human growth hormone by the eukaryotic alga, Chlorella. Current microbiology, 38(6), 335-341.

He, D. M., Qian, K. X., Shen, G. F., Zhang, Z. F., Yi-Nü, L. I., Su, Z. L., and Shao, H. B. (2007). Recombination and expression of classical swine fever virus $(\mathrm{CSFV})$ structural protein E2 gene in 
Chlamydomonas

reinhardtii chroloplasts. Colloids and surfaces B: Biointerfaces, 55(1), 26-30.

Hsieh, H. J., Su, C. H., and Chien, L. J. (2012). Accumulation of lipid production in Chlorella minutissima by triacylglycerol biosynthesis-related genes cloned from Saccharomyces cerevisiae and Yarrowia lipolytica. Journal of Microbiology, 50(3), 526534.

Huang, X., Weber, J. C., Hinson, T. K., Mathieson, A. C., and Minocha, S. C. (1996). Transient expression of the GUS reporter gene in the protoplasts and partially digested cells of Ulva lactuca L.(Chlorophyta). Botanica marina, 39(1-6), 467-474.

Jarvis, E. E., and Brown, L. M. (1991). Transient expression of firefly luciferase in protoplasts of the green alga Chlorella ellipsoidea. Current genetics, 19(4), 317-321.

Kajikawa, M., Kinohira, S., Ando, A., Shimoyama, M., Kato, M., and Fukuzawa, H. (2015). Accumulation of squalene in a microalga Chlamydomonas reinhardtii by genetic modification of squalene synthase and squalene epoxidase genes. PloS One, 10(3), e0120446.

Kathiresan, S., Chandrashekar, A., Ravishankar, G. A., and Sarada, R. (2009). Agrobacterium- mediated transformation in the green alga Haematococcus pluvialis (Chlorophyceae, Volvocales) 1. Journal of Phycology, 45(3), 642-649.

Kim, K. W., Bai, S. C., Koo, J. W., Wang, X., and Kim, S. K. (2002). Effects of dietary Chlorella ellipsoidea supplementation on growth, blood characteristics, and whole- body composition in juvenile Japanese flounder Paralichthys olivaceus. Journal of the World Aquaculture
Society, 33(4), 425-431.

Kindle, K. L. (1990). High-frequency nuclear transformation of Chlamydomonas reinhardtii. Proceedings of the National Academy of Sciences, 87(3), 1228-1232.

Kindle, K. L., Schnell, R. A., Fernández, E., and Lefebvre, P. A. (1989). Stable nuclear transformation of Chlamydomonas using the Chlamydomonas gene for nitrate reductase. The Journal of cell biology, 109(6), 2589-2601.

Kumar, S. V., Misquitta, R. W., Reddy, V. S., Rao, B. J., and Rajam, M. V. (2004). Genetic transformation of the green alga-Chlamydomonas reinhardtii by Agrobacterium tumefaciens. Plant Science, 166(3), 731-738.

La Russa, M., Bogen, C., Uhmeyer, A., Doebbe, A., Filippone, E., Kruse, O., and Mussgnug, J. H. (2012). Functional analysis of three type-2 DGAT homologue genes for triacylglycerol production in the green microalga Chlamydomonas reinhardtii. Journal of biotechnology, 162(1), 13-20.

Lapidot, M., Raveh, D., Sivan, A., Arad, S. M., and Shapira, M. (2002). Stable chloroplast transformation of the unicellular red alga Porphyridium species. Plant physiology, 129(1), 7-12.

Lauersen, K. J., Berger, H., Mussgnug, J. H., and Kruse, O. (2013). Efficient recombinant protein production and secretion from nuclear transgenes in Chlamydomonas reinhardtii. Journal of biotechnology, 167(2), 101-110.

León, R., Couso, I., and Fernández, E. (2007). Metabolic engineering of ketocarotenoids biosynthesis in the unicelullar microalga Chlamydomonas reinhardtii. Journal of biotechnology, 130(2), 143-152.

Liu, J., Gerken, H., Huang, J., and Chen, F. (2013). Engineering of an endogenous phytoene desaturase gene as a dominant 
selectable marker for Chlamydomonas reinhardtii transformation and enhanced biosynthesis of carotenoids. Process Biochemistry, 48(5), 788-795.

Liu, J., Sun, Z., Gerken, H., Liu, Z., Jiang, Y., and Chen, F. (2014). Chlorella zofingiensis as an alternative microalgal producer of astaxanthin: biology and industrial potential. Marine drugs, 12(6), 3487-3515.

Lumbreras, V., Stevens, D. R., and Purton, S. (1998). Efficient foreign gene expression in Chlamydomonas reinhardtii mediated by an endogenous intron. The Plant Journal, 14(4), 441447.

Ma, Y. H., Wang, X., Niu, Y. F., Yang, Z. K., Zhang, M. H., Wang, Z. M., and Li, H. Y. (2014). Antisense knockdown of pyruvate dehydrogenase kinase promotes the neutral lipid accumulation in the diatom Phaeodactylum tricornutum. Microbial cell factories, 13(1), 1-9.

Manuell, A. L., Beligni, M. V., Elder, J. H., Siefker, D. T., Tran, M., Weber, A., and Mayfield, S. P. (2007). Robust expression of a bioactive mammalian protein in Chlamydomonas chloroplast. Plant biotechnology journal, 5(3), 402412.

Mayfield, S. P., and Franklin, S. E. (2005). Expression of human antibodies in eukaryotic micro-algae. Vaccine, 23(15), 1828-1832.

Mayfield, S. P., and Schultz, J. (2004). Development of a luciferase reporter gene, luxCt, for Chlamydomonas reinhardtii chloroplast. The Plant Journal, 37(3), 449-458.

Mayfield, S. P., Franklin, S. E., and Lerner, R. A. (2003). Expression and assembly of a fully active antibody in algae. Proceedings of the National Academy of Sciences, 100(2), 438-442.

Men, S., Ming, X., Liu, R., Wei, C., and Li,
Y. (2003). Agrobacterium-mediated genetic transformation of a Dendrobium orchid. Plant Cell, Tissue and Organ Culture, 75(1), 63-71.

Miller, R., Wu, G., Deshpande, R. R., Vieler, A., Gärtner, K., Li, X., and Bullard, B. (2010). Changes in transcript abundance in Chlamydomonas reinhardtii following nitrogen deprivation predict diversion of metabolism. Plant physiology, 154(4), 1737-1752.

Minoda, A., Sakagami, R., Yagisawa, F., Kuroiwa, T., and Tanaka, K. (2004). Improvement of culture conditions and evidence for nuclear transformation by homologous recombination in a red alga, Cyanidioschyzon merolae 10D. Plant and Cell Physiology, 45(6), 667671.

Miyagawa, A., Okami, T., Kira, N., Yamaguchi, H., Ohnishi, K., and Adachi, M. (2009). Research note: high efficiency transformation of the diatom Phaeodactylum tricornutum with a promoter from the diatom Cylindrotheca fusiformis. Phycological Research, 57(2), 142-146.

Miyagawa- Yamaguchi, A., Okami, T., Kira, N., Yamaguchi, H., Ohnishi, K., and Adachi, M. (2011). Stable nuclear transformation of the diatom Chaetoceros sp. Phycological research, 59(2), 113-119.

Niu, Y. F., Zhang, M. H., Xie, W. H., Li, J. N., Gao, Y. F., Yang, W. D., and Li, H. Y. (2011). A new inducible expression system in a transformed green alga, Chlorella vulgaris. Genet. Mol. Res, 10, 3427-3434.

Ohresser, M., Matagne, R. F., and Loppes, R. (1997). Expression of the arylsulphatase reporter gene under the control of the nit1 promoter in Chlamydomonas reinhardtii. Current genetics, 31(3), 264-271.

Peng, K. T., Zheng, C. N., Xue, J., Chen, X. 
Y., Yang, W. D., Liu, J. S., and Li, H. Y. (2014). Delta 5 fatty acid desaturase upregulates the synthesis of polyunsaturated fatty acids in the marine diatom Phaeodactylum tricornutum. Journal of agricultural and food chemistry, 62(35), 8773-8776.

Purton, S., and Rochaix, J. D. (1995). Characterisation of the ARG7 gene of Chlamydomonas reinhardtii and its application to nuclear transformation. European Journal of Phycology, 30(2), 141-148.

Qin, S., Sun, G. Q., Jiang, P., Zou, L. H., Wu, Y., and Tseng, C. K. (1999). Review of genetic engineering of Laminaria japonica (Laminariales, Phaeophyta) in China. In Sixteenth International Seaweed Symposium (pp. 469-472). Springer Netherlands.

Radakovits, R., Eduafo, P. M., and Posewitz, M. C. (2011). Genetic engineering of fatty acid chain length in Phaeodactylum tricornutum. Metabolic engineering, 13(1), 89-95.

Radakovits, R., Jinkerson, R. E., Fuerstenberg, S. I., Tae, H., Settlage, R. E., Boore, J. L., and Posewitz, M. C. (2012). Draft genome sequence and genetic transformation of the oleaginous alga Nannochloropsis gaditana. Nature communications, 3, 686.

Randolph-Anderson, B. L., Sato, R., Johnson, A. M., Harris, E. H., Hauser, C. R., Oeda, K., and Boynton, J. E. (1998). Isolation and characterization of a mutant protoporphyrinogen oxidase gene from Chlamydomonas reinhardtii conferring resistance to porphyric herbicides. Plant molecular biology, 38(5), 839-859.

Rasala, B. A., Lee, P. A., Shen, Z., Briggs, S. P., Mendez, M., and Mayfield, S. P. (2012). Robust expression and secretion of Xylanasel in Chlamydomonas reinhardtii by fusion to a selection gene and processing with the FMDV 2A peptide. PLoS One, 7(8), e43349.

Rasala, B. A., Muto, M., Lee, P. A., Jager, M., Cardoso, R. M., Behnke, C. A., and Mayfield, S. P. (2010). Production of therapeutic proteins in algae, analysis of expression of seven human proteins in the chloroplast of Chlamydomonas reinhardtii. Plant biotechnology journal, 8(6), 719-733.

Rathod, J. P., Prakash, G., Pandit, R., and Lali, A. M. (2013). Agrobacteriummediated transformation of promising oil-bearing marine algae Parachlorella kessleri. Photosynthesis research, 118(1-2), 141-146.

Rathod, J. P., Prakash, G., Vira, C., and Lali, A. M. (2016). Trehalose phosphate synthase overexpression in Parachlorella kessleri improves growth and photosynthetic performance under high light conditions. Preparative Biochemistry and Biotechnology, 46(8), 803-809.

Sharif, N., Munir, N., Saleem, F., and Naz, S. (2015). Factors affecting Agrobacterium mediated transformation of indigenous Chlorella vulgaris bayerinck. Bangladesh journal of botany, 44(2), 323-326.

Sode, K., Tatara, M., Takeyama, H., Burgess, J. G., and Matsunaga, T. (1992). Conjugative gene transfer in marine cyanobacteria: Synechococcus sp., Synechocystis sp. and Pseudanabaena sp. Applied microbiology and biotechnology, 37(3), 369-373.

Stachel, S. E., Messens, E., Van Montagu, M., and Zambryski, P. (1985). Identification of the signal molecules produced by wounded plant cells that activate $\mathrm{T}$ DNA transfer in Agrobacterium tumefaciens. Nature, 318, 624-629.

Steinbrenner, J., and Sandmann, G. (2006). Transformation of the green alga Haematococcus pluvialis with a 
phytoene desaturase for accelerated astaxanthin biosynthesis. Applied and environmental microbiology, 72(12), 7477-7484.

Stevens, D. R., Purton, S., and Rochaix, J. D. (1996). The bacterial phleomycin resistance geneble as a dominant selectable marker in Chlamydomonas. Molecular and General Genetics $M G G$, 251(1), 23-30.

Sun, M., Qian, K., Su, N., Chang, H., Liu, J., and Shen, G. (2003). Foot-and-mouth disease virus VP1 protein fused with cholera toxin B subunit expressed in Chlamydomonas reinhardtii chloroplast. Biotechnology letters, 25(13), 1087-1092.

Sun, N., Wang, Y., Li, Y. T., Huang, J. C., and Chen, F. (2008). Sugar-based growth, astaxanthin accumulation and carotenogenic transcription of heterotrophic Chlorella zofingiensis (Chlorophyta). Process Biochemistry, 43(11), 1288-1292.

Surzycki, R., Greenham, K., Kitayama, K., Dibal, F., Wagner, R., Rochaix, J. D., and Surzycki, S. (2009). Factors effecting expression of vaccines in microalgae. Biologicals, 37(3), 133 138.

Tan, C., Qin, S., Zhang, Q., Jiang, P., and Zhao, F. (2005). Establishment of a micro-particle bombardment transformation system for Dunaliella salina. Journal of Microbiology-Seoul-, 43(4), 361.

Te, M. R., and Miller, D. J. (1998). Genetic transformation of dinoflagellates (Amphidinium and Symbiodinium): expression of $G U S$ in microalgae using heterologous promoter constructs. The Plant Journal, 13(3), 427-435.

Tirichine, L., and Bowler, C. (2011). Decoding algal genomes: tracing back the history of photosynthetic life on Earth. The Plant Journal, 66(1), 45-57.
Tolonen, A. C., Aach, J., Lindell, D., Johnson, Z. I., Rector, T., Steen, R., and Chisholm, S. W. (2006). Global gene expression of Prochlorococcus ecotypes in response to changes in nitrogen availability. Molecular systems biology, 2(1), 53.

Tran, M., Zhou, B., Pettersson, P. L., Gonzalez, M. J., and Mayfield, S. P. (2009). Synthesis and assembly of a full- length human monoclonal antibody in algal chloroplasts. Biotechnology and bioengineering, 104(4), 663-673.

Trentacoste, E. M., Shrestha, R. P., Smith, S. R., Glé, C., Hartmann, A. C., Hildebrand, M., and Gerwick, W. H. (2013). Metabolic engineering of lipid catabolism increases microalgal lipid accumulation without compromising growth. Proceedings of the National Academy of Sciences, 110(49), 1974819753.

Vila, M., Couso, I., and León, R. (2008). Carotenoid content in mutants of the chlorophyte Chlamydomonas reinhardtii with low expression levels of phytoene desaturase. Process biochemistry, 43(10), 1147-1152.

Vira, C., Prakash, G., Rathod, J. P., and Lali, A. M. (2016). Cloning, expression, and purification of Chlamydomonas reinhardtii CC-503 sedoheptulose 1, 7bisphosphatase in Escherichia coli. Preparative Biochemistry and Biotechnology, 46(8), 810-814.

Wang, X., Brandsma, M., Tremblay, R., Maxwell, D., Jevnikar, A. M., Huner, N., and Ma, S. (2008). A novel expression platform for the production of diabetes-associated autoantigen human glutamic acid decarboxylase (hGAD65). BMC Biotechnology, 8(1), 87.

Watahiki, M., Yamamoto, M., Yamakawa, M., Tanaka, M., and Nakashima, K. 
(1989). Conserved and unique amino acid residues in the domains of the growth hormones. Flounder growth hormone deduced from the cDNA sequence has the minimal size in the growth hormone prolactin gene family. Journal of Biological Chemistry, 264(1), 312-316.

Wong, K.H.(2006). Transgenic Chlamydomonas reinhardtii as an experimental system to study the regulation of carotenoid biosynthesis in green microalgae. Ph.D. thesis, The University of HongKong, HongKong.

Wu-Scharf, D., Jeong, B. R., Zhang, C., and Cerutti, H. (2000). Transgene and transposon silencing in Chlamydomonas reinhardtii by a DEAH-box RNA helicase. Science, 290(5494), 11591162.

Xue, J., Niu, Y. F., Huang, T., Yang, W. D., Liu, J. S., and Li, H. Y. (2015). Genetic improvement of the microalga Phaeodactylum tricornutum for boosting neutral lipid accumulation. Metabolic engineering, 27, 1-9.

Yang, Z., Chen, F., Li, D., Zhang, Z., Liu, Y., Zheng, D., and Shen, G. (2006). Expression of human soluble TRAIL in Chlamydomonas reinhardtii chloroplast. Chinese Science Bulletin, 51(14), 1703-1709.

Yohn, C., Brand, A., Mendez, M., and Behnke, C. A. (2011). U.S. Patent Application No. 13/576,821.

Zaslavskaia, L. A., Lippmeier, J. C., Shih, C., Ehrhardt, D., Grossman, A. R., and Apt, K. E. (2001). Trophic conversion of an obligate photoautotrophic organism through metabolic engineering. Science, 292(5524), 2073-2075.

Zäuner, S., Jochum, W., Bigorowski, T., and Benning, C. (2012). A cytochrome b5containing plastid-located fatty acid desaturase from Chlamydomonas reinhardtii. Eukaryotic cell, 11(7), 856863.

Zeng, X., Danquah, M. K., Chen, X. D., and Lu, Y. (2011). Microalgae bioengineering: from $\mathrm{CO}_{2}$ fixation to biofuel production. Renewable and Sustainable Energy Reviews, 15(6), 3252-3260.

Zhang, Y. K., Shen, G. F., and Ru, B. G. (2006). Survival of human metallothionein- 2 transplastomic Chlamydomonas reinhardtii to ultraviolet B exposure. Acta biochimica et biophysica Sinica, 38(3), 187-193.

\section{How to cite this article:}

Jayant Pralhad Rathod, Rajendra M. Gade, Darasing R. Rathod and Mahendra Dudhare. 2017. A Review on Molecular Tools of Microalgal Genetic Transformation and their Application for Overexpression of Different Genes. Int.J.Curr.Microbiol.App.Sci. 6(12): 3191-3207. doi: https://doi.org/10.20546/ijcmas.2017.612.373 